\title{
The relationship between Candida species cultured from the respiratory tract and systemic inflammation in critically ill patients with ventilator-associated pneumonia La relation entre la mise en culture de Candida prélevée dans les
voies respiratoires et l'inflammation systémique chez les patients
gravement malades atteints de pneumonie sous ventilation assistée
}

\author{
David R. Williamson, MSc • Martin Albert, MD - Marc M. Perreault, PharmD • \\ Marie-Soleil Delisle, MSc • John Muscedere, MD • Coleman Rotstein, MD • \\ Xuran Jiang, MSc $\cdot$ Daren K. Heyland, MD
}

Received: 29 July 2010/Accepted: 1 December 2010/Published online: 14 December 2010

(C) Canadian Anesthesiologists' Society 2010

\begin{abstract}
Purpose In patients with ventilator-associated pneumonia (VAP), the isolation of Candida species (spp.) in respiratory secretions has been associated with worse outcomes. It is unclear whether Candida colonization is causally related or is a marker of disease severity. The objective of this study was to compare systemic inflammatory markers in patients with a clinical suspicion of VAP with Candida in respiratory tract $(R T)$ cultures vs patients who have bacteria and those with no pathogens.

Methods This was a prospective observational study in adults with a clinical suspicion of VAP who were enrolled within $24 \mathrm{hr}$ of intensive care unit (ICU) admission. Patients were divided into four groups according to $R T$ cultures, i.e., bacterial pathogens only, Candida spp. only, culture negative, and a control group with no clinical suspicion of VAP. Clinical outcomes were collected and
\end{abstract}

D. R. Williamson, MSc

Department of Pharmacy Services, Hôpital du Sacré-Cœur de Montréal, Montréal, QC, Canada

D. R. Williamson, MSc $(\bowtie) \cdot$ M. M. Perreault, PharmD Faculté de Pharmacie, Université de Montréal, C.P. 6128, Succursale Centre-ville, Montréal, QC H3C 3J7, Canada

M. Albert, MD

Department of Critical Care, Hôpital du Sacré-Cœur de Montréal, Montréal, QC, Canada

M. Albert, MD

Faculté de Médecine, Université de Montréal, Montréal, QC, Canada compared as were systemic inflammatory and coagulation markers, including procalcitonin (PCT), C-reactive protein (CRP) and interleukin (IL)-6.

Results The PCT, CRP, and IL-6 levels were similar in the Candida, bacterial pathogen, and culture negative groups but were significantly increased between the Candida group and the control group $(P<0.05)$. In the first 28 days, the number of ICU free days was significantly lower in the Candida group compared with the other groups, and mortality at 28 days was greater (Candida $42.9 \%$, bacterial pathogen $25.0 \%$, culture negative $19.8 \%$, control $0.0 \% ; P<0.05)$.

Conclusions In patients with a clinical suspicion of VAP, the presence of Candida spp. only in the RT is associated with similar levels of inflammation and worse clinical outcomes compared with patients without Candida in RT secretions.

M. M. Perreault, PharmD - M.-S. Delisle, MSc

Department of Pharmacy Services, McGill University Health Centre, Montreal General Hospital, Montreal, QC, Canada

J. Muscedere, MD $\cdot$ X. Jiang, MSc $\cdot$ D. K. Heyland, MD Clinical Evaluation Research Unit, Queen's University, Kingston General Hospital, Kingston, ON, Canada

J. Muscedere, MD · D. K. Heyland, MD

Department of Medicine, Queen's University, Kingston General Hospital, Kingston, ON, Canada

C. Rotstein, MD

Division of Infectious Diseases, University of Toronto, University Health Network, Toronto General Hospital, Toronto, ON, Canada 


\section{Résumé}

Objectif Chez les patients atteints de pneumonie sous ventilation assistée (PVA), l'isolation d'une espèce de Candida (spp.) dans les sécrétions respiratoires a été associée à un pronostic défavorable. Nous ne savons pas si la colonisation de Candida est la cause de la gravité de la maladie ou si elle en est un marqueur. L'objectif de cette étude était de comparer des marqueurs de l'inflammation systémique chez des patients pour lesquels on soupçonnait cliniquement une PVA avec Candida dans les cultures des voies respiratoires (VR) à des patients avec bactéries et à d'autres ne présentant pas de pathogènes.

Méthode Cette étude observationnelle prospective a été réalisée chez des adultes chez lesquels on soupçonnait cliniquement une PVA et qui ont été recrutés dans les 24 heures suivant leur admission à l'unité des soins intensifs (USI). Les patients ont été répartis en quatre groupes selon les cultures de leurs $V R$, soit pathogènes bactériens seulement, Candida spp. seulement, culture négative et un groupe témoin sans suspicion clinique de PVA. Les devenirs cliniques ont été colligés et comparés, tout comme les marqueurs d'inflammation systémique et de coagulation, y compris la procalcitonine (PCT), la protéine $C$-réactive (CRP) et l'interleukine (IL)-6.

Résultats Les niveaux de PCT, de CRP et d'IL-6 étaient semblables dans les groupes Candida, pathogènes bactériens et culture négative, mais étaient significativement plus élevés dans le groupe Candida par rapport au groupe témoin $(P<0,05)$. Au cours des premiers 28 jours, le nombre de jours hors de l'USI était significativement plus bas dans le groupe Candida par rapport aux autres groupes, et la mortalité à 28 jours était plus élevée (Candida 42,9\%, pathogènes bactériens 25,0\%, culture négative 19,8\%, témoin 0,0\%; $P<0,05$ ).

Conclusion Chez les patients chez lesquels on soupçonne cliniquement une PVA, la présence de Candida spp. seulement dans les $V R$ est associée à des niveaux d'inflammation semblables et des devenirs cliniques moins bons que chez les patients qui n'ont pas de Candida dans leurs sécrétions des VR.

Nosocomial infections are a major complication in intensive care unit (ICU) patients. ${ }^{1,2}$ Among these, hospitalacquired pneumonia is encountered the most frequently, and ventilator-associated pneumonia (VAP) accounts for the majority of these infections. Increased morbidity, mortality, and health care costs have been attributed to $\mathrm{VAP}^{3-8}$ The pathogens most commonly recovered in VAP are Pseudomonas aeruginosa, Enterobacteriaceae, and Staphylococcus aureus. ${ }^{9}$

However, recent studies in the ICU have demonstrated that Candida species (spp.) are also consistently recovered from the lungs of critically ill patients. ${ }^{10,11}$ In the recent Canadian VAP trial, Candida spp. were identified in the pulmonary cultures of $16 \%$ of patients with suspected VAP upon enrolment. ${ }^{10}$ Historically, the presence of Candida spp. in the respiratory tract (RT) has been considered colonization, and Candida pneumonia, as defined by evidence of invasive disease, is rare in critically ill patients. ${ }^{12-14}$ However, Candida colonization at one or multiple sites, including the RT, has been identified as an independent risk factor for candidemia. ${ }^{15,16}$

In a recent analysis of the Canadian VAP study, the presence of Candida isolated solely from RT secretions was associated with a significant increase in median hospital stay (59.9 vs 38.6 days; $P=0.006)$ and hospital mortality (34.2\% vs $21.0 \% ; P=0.003)$, while being independently associated with hospital mortality in a multivariable regression model (odds ratio [OR] 2.47, 95\% confidence intervals [CI] 1.39-4.37). ${ }^{17}$ In addition, an association between the presence of Candida in the RT secretions, prolonged mechanical ventilation, and increased length of hospitalization has also been reported. $^{18}$ It is unclear whether Candida colonization is causally related or is a marker of disease severity.

Pneumocystis jiroveci, another $\beta$-glucan containing organism, has shown an association with systemic inflammation with colonization. ${ }^{19}$ In addition, procalcitonin (PCT), tumour necrosis factor alpha (TNF- $\alpha$ ), and interleukin (IL)-6 are elevated in infection and have been associated with worse outcomes in critically ill patients. Hence, evaluating the relationship between markers of systemic inflammation and the presence of Candida in RT secretions may provide insight as to the impact of Candida on patient outcomes. ${ }^{20,21}$ Hypothetically, a low level of systemic inflammation would be inconsistent with Candida playing a central pathogenic role, whereas, increased levels could mean that either Candida presence in the lungs is causing systemic inflammation or that increased inflammation enhances patients' predilection to harbour Candida. The null hypothesis is that inflammatory markers are significantly lower in patients harbouring Candida than in those growing bacteria. Thus, the primary objective of this study was to compare the profile of key markers of systemic inflammation in patients with clinically suspected VAP who had only Candida isolated in RT secretions with that of patients who had only bacteria isolated, patients without isolated pathogens, and a group of control patients without clinically suspected VAP. 


\section{Methods}

This was a prospective observational study conducted in three Canadian tertiary care ICUs from October 2002 to October 2003. All patients 18 yrs-of-age and older were enrolled within $24 \mathrm{hr}$ of ICU admission. Exclusion criteria included patients with elective surgery, overdoses, and those whose expected stay was less than $24 \mathrm{hr}$. Of all study patients enrolled, we focused on a subset of patients with a clinical suspicion of VAP that evolved more than $48 \mathrm{hr}$ after admission to ICU. We defined clinically suspected VAP as the presence of a pulmonary infiltrate on chest $x$-ray with clinical systemic inflammatory response syndrome (i.e., at least two of the following four criteria: fever $>38^{\circ} \mathrm{C}$, leukocytosis $\left[>11.0 \times 10^{9} \cdot \mathrm{L}^{-1}\right]$ or neutropenia $[<3.5 \times$ $\left.10^{9} \cdot \mathrm{L}^{-1}\right]$, tachycardia $>100$ beats. $\min ^{-1}$, and tachypnea $>20$ breaths $\cdot \min ^{-1}$ ), along with a sampling of RT secretions for culture, and a prescription for new antibiotics. For the sampling of RT secretions, bronchoalveolar lavage and/or endotracheal aspiration were performed according to local standards. Based on the culture results, these patients were then separated into three groups: Candida only, isolation of bacterial pathogens only, and those with cultures negative for Candida or bacterial pathogens. As the overall objective of this study was to assess the relationship between systemic inflammation and Candida from the RT, we excluded patients with both bacteria and Candida in the RT secretions and patients with Candida from other non-pulmonary sites. So as not to obfuscate the signal, patients with organisms with uncertain pathogenicity were also excluded. Patients with organisms consistent with bacterial commensal flora were included in the no pathogen group. This categorization of the larger study population into homogenous groups was carried out to obtain the most robust evaluation of the effects of isolated RT cultured pathogens on systemic inflammation. Two investigators reviewed the clinical records of the study patients and further excluded patients with a non-respiratory source of infection within 72 $\mathrm{hr}$ before or after the index RT cultures were taken. Finally, patients who did not receive antibiotics and had no RT cultures during the study period were included in the analysis as a control group (i.e., no suspicion of VAP).

Local institutional research ethics boards approved the protocol, and informed consent was obtained prior to enrolment. The clinical management of patients was determined by the clinical team caring for the patients as per the clinical protocols operational in each respective ICU.

\section{Data collection}

We obtained baseline demographics, pertinent clinical data, and medications either from the patients or from their medical records. Necessary variables were recorded in order to calculate the Acute Physiological and Chronic Health Assessment (APACHE) $\mathrm{II}^{22}$ on admission and the daily Sequential Organ Failure Assessment (SOFA) scores ${ }^{23}$ until day ten, discharge from the ICU, or death.

Blood samples were collected for analysis in the morning following enrolment and each subsequent ICU day until discharge, death, or a maximum of ten days. Plasma was analyzed for inflammatory and coagulation markers using the following assays: protein $\mathrm{C}$ (MDA ${ }^{\circledR}$ Protein $\mathrm{C}$ assay kit, Organon Teknika Corporation, Durham, NC, USA), antithrombin (MDA ${ }^{\circledR}$ Antithombin III assay kit, BioMerieux, Inc. Durham, NC, USA), D-Dimer (MDA ${ }^{\circledR}$ D-Dimer assay kit, Organon Teknika Corporation, Durham, NC, USA), IL-6 (Bender Medsystems ELISA kitCat BMS-213 [Bender Med systems Inc, Burlingame, CA, USA]), and PCT (BRAHMS PCT LIA assay, Hennigsdorf, Germany). C-reactive protein (CRP), fibrinogen, and cholesterol levels were analyzed at local institutions according to standard laboratory operating procedures.

The clinical outcomes for this study included 14-day, 28-day, and hospital mortality; ICU and ventilator free days in the first 28 days; and maximum and delta SOFA scores. The SOFA score was calculated using a revised rule: regardless of their creatinine levels, patients on dialysis were assigned a score of 4 for renal domain on that day. Physicians were blinded to the results of blood tests measured specifically for this study, but not to routine tests.

\section{Statistical analysis}

Categorical variables were described as counts and percentages and compared using Chi square tests, whereas continuous variables were described as means with standard deviations and compared using one-way analysis of variance. Pair-wise comparisons were performed between the Candida only group and all other groups for all variables reaching an overall level of significance of 0.05. Biomarkers were described as medians with quartiles and compared using Kruskal-Wallis testing. A linear mixed-effects model for repeated measures was used to compare the means of the four groups across all study days. This model was estimated by restricted maximum likelihood. An additional regression model was built to describe variables associated with 28-day mortality; those variables significant in univariate analysis $(P<0.05)$ were further evaluated in the multivariable logistic regression analysis. The SAS (version 9.1; SAS Institute, Cary, NC, USA) statistical software package was used for all statistical analyses.

\section{Results}

Of the 598 patients enrolled in the initial study, 28 patients had no antibiotics prescribed and no cultures sent for 
laboratory analysis during their ICU stay. Three of these patients were excluded from analysis because of death within $72 \mathrm{hr}$ (two patients) and bacterial infection before admission (one patient). The remaining 25 patients were assessed as not having suspected VAP and served as a control group (Fig. 1). Of the remaining 570 patients, 359 patients were excluded because their respiratory cultures were not sent for laboratory analysis following $48 \mathrm{hr}$ of admission. Thus, there were 211 patients with suspected VAP. An additional 41 patients were excluded for the following reasons: ten patients had both bacteria and Candida spp. in the respiratory specimens; 14 patients had a non-respiratory source of infection; 14 patients had an uncertain pathogenic organism; one patient received fluconazole for more than a week; and two patients had positive Candida spp. cultures in both respiratory and blood cultures. Of the remaining 170 patients, 81 patients had no growth or commensal flora in their respiratory specimens; 68 patients had pathogenic bacteria only, and 21 patients had Candida spp. only. No patients in the Candida group received antifungal therapy. In the culture negative group, commensal flora was recovered in 29 patients (35.8\%), and Aspergillus spp. was considered to be a contaminant in one patient $(1.2 \%)$. The organisms recovered most frequently in the bacterial pathogen only group were methicillin-sensitive Staphylococcus aureus (26.5\%), Pseudomonas species (16.2\%), methicillin-resistant Staphylococcus aureus (10.3\%), and Streptococcus species $(5.9 \%)$. Patient characteristics from all four groups are compared in Table 1 . There were significant differences in baseline characteristics across the four groups with respect to APACHE II and SOFA scores, admission diagnoses, $\mathrm{PaO}_{2} / \mathrm{F}_{1} \mathrm{O}_{2}$ ratio, white blood cell count, and vasopressor use (see Table 1). The numbers of patients with cancer, metastatic cancer, leukemia, or lymphoma were similar across the groups; control group: $2 / 25$ (8\%), Candida group: 2/22 (9\%), bacterial pathogen group 7/68 $(10 \%)$, and culture negative group 10/81 $(12 \%) ;(P=\mathrm{NS})$. Patients in the Candida group were admitted mostly for respiratory illnesses, and they had a higher rate of prior use of antibiotics (61.9\%) than the bacterial pathogen (47.1\%) and culture negative $(55.6 \%)$ groups.

Patient outcomes (i.e., maximum SOFA score, delta SOFA score, number of days on mechanical ventilation, and number of ICU days) were significantly worse in the Candida group than in the control group, but they were comparable with the bacterial pathogen and culture negative groups (Table 2). The number of ICU free days within

Fig. 1 Patient flowchart

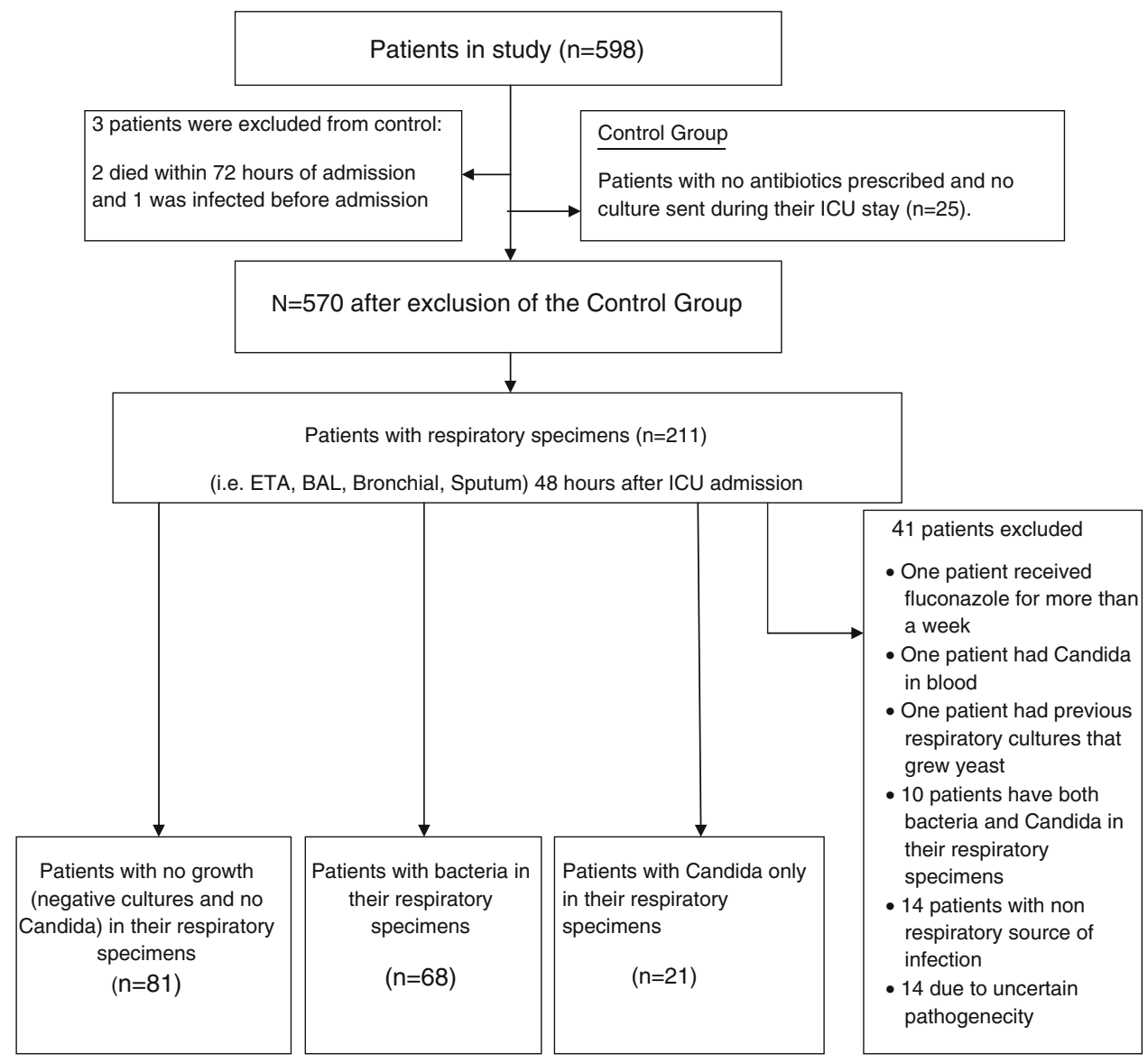


Table 1 Patient characteristics

\begin{tabular}{|c|c|c|c|c|}
\hline & $\begin{array}{l}\text { Control group } \\
(n=25)\end{array}$ & $\begin{array}{l}\text { Candida only } \\
(n=21)\end{array}$ & $\begin{array}{l}\text { Bacteria only } \\
(n=68)\end{array}$ & $\begin{array}{l}\text { Negative cultures } \\
\text { and no Candida }(n=81)\end{array}$ \\
\hline Age & $51.6 \pm 19.7$ & $63.7 \pm 17.1$ & $61.9 \pm 14.3$ & $62.2 \pm 16.5$ \\
\hline Sex Male & $12(48.0 \%)$ & $7(33.3 \%)$ & $43(63.2 \%)$ & $46(56.8 \%)$ \\
\hline APACHE II & $12.3 \pm 6.4$ & $24.1 \pm 7.5$ & $22.1 \pm 7.6$ & $22.2 \pm 7.6$ \\
\hline Baseline SOFA & $1.3 \pm 1.6$ & $5.5 \pm 3.1$ & $4.9 \pm 2.5$ & $5.5 \pm 2.7$ \\
\hline Number of co-morbidities & $3.1 \pm 1.4$ & $3.3 \pm 1.1$ & $2.9 \pm 1.4$ & $2.9 \pm 1.4$ \\
\hline \multicolumn{5}{|l|}{ Admission } \\
\hline Medical & $18(72.0 \%)$ & $19(90.5 \%)$ & $44(64.7 \%)$ & $56(69.1 \%)$ \\
\hline Surgical & $7(28.0 \%)$ & $2(9.5 \%)$ & $24(35.3 \%)$ & $25(30.9 \%)$ \\
\hline $\begin{array}{l}\text { Number of days from index date } \\
\text { to ICU admission ICU a }\end{array}$ & & $4.9 \pm 2.1$ & $4.1 \pm 2.0$ & $4.2 \pm 1.9$ \\
\hline \multicolumn{5}{|l|}{ Primary admission diagnosis } \\
\hline Cardiovascular/vascular & $3(12.0 \%)$ & $2(9.5 \%)$ & $5(7.4 \%)$ & $8(9.9 \%)$ \\
\hline Respiratory & $2(8.0 \%)$ & $13(61.9 \%)$ & $21(30.9 \%)$ & $32(39.5 \%)$ \\
\hline Gastrointestinal & $3(12.0 \%)$ & $2(9.5 \%)$ & $7(10.3 \%)$ & $11(13.6 \%)$ \\
\hline Neurologic & $2(8.0 \%)$ & $1(4.8 \%)$ & $5(7.4 \%)$ & $3(3.7 \%)$ \\
\hline Sepsis & $0(0.0 \%)$ & $2(9.5 \%)$ & $7(10.3 \%)$ & $2(2.5 \%)$ \\
\hline Trauma & $4(16.0 \%)$ & $0(0.0 \%)$ & $11(16.2 \%)$ & $8(9.9 \%)$ \\
\hline Metabolic & $7(28.0 \%)$ & $1(4.8 \%)$ & $4(5.9 \%)$ & $4(4.9 \%)$ \\
\hline Post-operative conditions & $4(16.0 \%)$ & $0(0.0 \%)$ & $6(8.8 \%)$ & $10(12.3 \%)$ \\
\hline Renal & $0(0.0 \%)$ & $0(0.0 \%)$ & $1(1.5 \%)$ & $1(1.2 \%)$ \\
\hline Orthopedic & $0(0.0 \%)$ & $0(0.0 \%)$ & $1(1.5 \%)$ & $2(2.5 \%)$ \\
\hline Prior use of antibiotics & $2(8.0 \%)$ & $13(61.9 \%)$ & $32(47.1 \%)$ & $45(55.6 \%)$ \\
\hline \multicolumn{5}{|l|}{ Data on ICU admission day } \\
\hline Heart rate & $103.1 \pm 21.0$ & $116.9 \pm 22.1$ & $114.0 \pm 24.6$ & $118.3 \pm 28.2$ \\
\hline Temperature & $37.5 \pm 0.7$ & $37.6 \pm 1.2$ & $37.4 \pm 1.4$ & $37.7 \pm 1.2$ \\
\hline Respiratory rate & $22.4 \pm 8.6$ & $30.5 \pm 10.4$ & $25.7 \pm 9.7$ & $26.8 \pm 10.4$ \\
\hline $\mathrm{PF}$ ratio & $369.6 \pm 306.9$ & $120.5 \pm 76.4$ & $174.9 \pm 110.2$ & $182.0 \pm 149.4$ \\
\hline WBC & $10.6 \pm 4.1$ & $18.3 \pm 9.8$ & $11.7 \pm 7.4$ & $14.4 \pm 9.0$ \\
\hline Vasopressor use Yes & $1(4.0 \%)$ & $10(47.6 \%)$ & $16(23.5 \%)$ & $18(22.2 \%)$ \\
\hline
\end{tabular}

Data shown as Mean \pm standard deviation or $n(\%)$

APACHE Acute Physiological and Chronic Health Assessment, SOFA Sequential Organ Failure Assessment, ICU intensive care unit, $P F$ the ratio of arterial oxygen concentration to the fraction of inspired oxygen, $W B C$ white blood cells

the first 28 days was significantly lower in the Candida group $(6.2 \pm 7.7)$ compared with the control $(24.9 \pm 1.2)$, bacterial pathogen $(8.9 \pm 8.3)$, and culture negative groups $(11.0 \pm 8.8)(P<0.001)$. Mortality at 28 days was greater in the Candida group (42.9\%) compared with the bacterial pathogen $(25.0 \%)$, culture negative $(19.8 \%)$, and control groups $(0.0 \%)(P<0.05)$. In a multivariate analysis evaluating factors associated with 28-day mortality, the APACHE II score was the only variable independently associated with increased mortality (OR 1.12, 95\% CI 1.04-1.20; $P=0.002)$. We encountered no increase in pseudomonal pneumonia in Candida spp. patients, as only one patient (4.5\%) subsequently developed Pseudomonas spp. in the RT secretions. Compared with the control group, C-reactive protein, IL-6, and PCT levels increased in all groups within $24 \mathrm{hr}$ of culture results (Table 3). Median PCT levels within $24 \mathrm{hr}$ of culture results were greatest in the Candida group $\left(1.4 \mathrm{ng} \cdot \mathrm{mL}^{-1}\right)$ compared with the control group $\left(0.2 \mathrm{ng} \cdot \mathrm{mL}^{-1}\right)$, bacterial pathogen group $\left(0.8 \mathrm{ng} \cdot \mathrm{mL}^{-1}\right)$ and culture negative group $\left(0.9 \mathrm{ng} \cdot \mathrm{mL}^{-1}\right)(P=0.02)$ (Table 3$)$. No statistical differences between groups were observed for D-dimer, protein $\mathrm{C}$, and antithrombin levels within $24 \mathrm{hr}$ of culture results. Total cholesterol and high-density lipoprotein (HDL)cholesterol were decreased significantly in the Candida, bacterial pathogen, and culture negative groups compared with the control group (Table 3).

In the days preceding and in the week following cultures, CRP, IL-6, and PCT levels were greater in the Candida, bacterial pathogen, and culture negative groups 
Table 2 Clinical outcomes

\begin{tabular}{|c|c|c|c|c|c|}
\hline & $\begin{array}{l}\text { Control group } \\
(n=25)\end{array}$ & $\begin{array}{l}\text { Candida only } \\
(n=21)\end{array}$ & $\begin{array}{l}\text { Bacteria only } \\
(n=68)\end{array}$ & $\begin{array}{l}\text { Negative cultures } \\
\text { and no Candida } \\
(n=81)\end{array}$ & $P$ values \\
\hline Maximum SOFA & $3.2 \pm 2.0$ & $10.4 \pm 3.3$ & $9.7 \pm 4.2$ & $9.8 \pm 4.0$ & $<0.001 *$ \\
\hline Delta SOFA & $2.3 \pm 2.2$ & $5.0 \pm 2.9$ & $4.9 \pm 3.5$ & $4.4 \pm 3.0$ & $0.03 *$ \\
\hline Number of days on MV & $0.6 \pm 0.8$ & $11.0 \pm 4.7$ & $10.3 \pm 8.0$ & $9.0 \pm 5.2$ & $<0.001 *$ \\
\hline Number of days in ICU & $3.1 \pm 1.2$ & $19.3 \pm 17.6$ & $18.5 \pm 17.5$ & $16.7 \pm 19.3$ & $0.001 *$ \\
\hline ICU free days in the first 28 days & $24.9 \pm 1.2$ & $6.2 \pm 7.7$ & $8.9 \pm 8.3$ & $11.0 \pm 8.8$ & $<0.001 * t$ \\
\hline Mortality at day 14 & $0(0.0 \%)$ & $4(19.0 \%)$ & $12(17.6 \%)$ & $12(14.8 \%)$ & 0.16 \\
\hline Mortality at day 28 & $0(0.0 \%)$ & $9(42.9 \%)$ & $17(25.0 \%)$ & $16(19.8 \%)$ & 0.004 \\
\hline Duration of antibiotics (days) & $0.0 \pm 0.0$ & $11.2 \pm 8.8$ & $17.5 \pm 9.4$ & $16.9 \pm 10.4$ & $<0.001 * \dagger$ \\
\hline $\begin{array}{l}\text { Days alive and off all antibiotics in } \\
\text { the first } 28 \text { days (from ICU admission) }\end{array}$ & $28.0 \pm 0.0$ & $11.2 \pm 10.1$ & $6.8 \pm 8.6$ & $8.6 \pm 10.3$ & $<0.001 *$ \\
\hline
\end{tabular}

Pair-wise comparisons were performed between the Candida only group $v s$ the other groups for variables reaching an overall level of significance of 0.05. * Candida vs control group; $\dagger$ Candida vs bacteria group; $\$$ Candida vs negative group. SOFA = Sequential Organ Failure Assessment; $\mathrm{MV}=$ mechanical ventilation; ICU $=$ intensive care unit

compared with the control group without reaching statistical significance (Figs 2, 3, and 4).

\section{Discussion}

In order to assess whether Candida.isolated in RT secretions is associated with systemic inflammation, we conducted an analysis of the systemic inflammatory markers of patients who developed a clinical suspicion of VAP from a large multicentre observational study in a heterogeneous ICU population. Our main finding was that Candida in the RT secretions in patients with suspected VAP was associated with increased levels of PCT, IL-6, and CRP. These increased levels were similar to the increased levels in patients with both positive bacterial cultures and negative culture results, and they were statistically increased compared with our control patients. Moreover, 28-day mortality was significantly increased in the Candida group compared with the bacterial pathogen and culture negative groups. However, in our multivariate analysis, only the APACHE II score was independently associated with increased mortality. Presence of Candida in the RT was not significantly associated with mortality.

The purpose of evaluating these inflammatory markers associated with the presence of Candida in the RT for patients with suspected VAP was to assess whether Candida may predispose such patients to a negative outcome. Based on our findings, we reject our null hypothesis that Candida is associated with low levels of systemic inflammation. The question remaining is whether Candida in the airways is directly responsible for worse clinical outcomes or whether the presence of Candida is merely a marker for severity of disease.

Candida spp. are normal commensals of the human body. They are commonly found on the skin, gastrointestinal tract, genitourinary tract, and RT, and they occupy a unique ecological niche. However, in critically ill patients, there may be perturbations in patients' homeostasis under the influence of risk factors, such as broad spectrum antibacterial therapy, leading to the proliferation of Candida organisms usually kept in check by bacterial organisms beyond their normal niche. At such times, invasive Candida infection may arise, particularly in the presence of mucosal barrier damage. This concept of invasion based on organism density has been demonstrated previously by the translocation of Candida from the gastrointestinal tract in the presence of high organism loads. ${ }^{24,25}$ Such invasion could easily enhance the propensity to produce systemic inflammation. In critically ill patients, maintenance of normal microbial flora and an intact immune system is rare, as antibiotics and relative immunosuppression (corticosteroids, late sepsis) are common, thus promoting Candida colonization and perhaps infection. Yet, Candida pneumonia is uncommon, and its diagnosis must be secured by demonstrating the presence of yeast or pseudohyphae in lung tissue. ${ }^{9}$ Perhaps this paradigm is shifting, as the presence of Candida spp. in the RT specimens of patients on mechanical ventilation in the ICU, independent of the histological diagnosis of VAP, may have more significance than previously considered.

Candida possesses a $\beta$-glucan-rich cell wall that has been shown to activate immune responses. ${ }^{26-28}$ Studies with Pneumocystis jiroveci and fungi have demonstrated that B-glucans can stimulate the release of inflammatory 


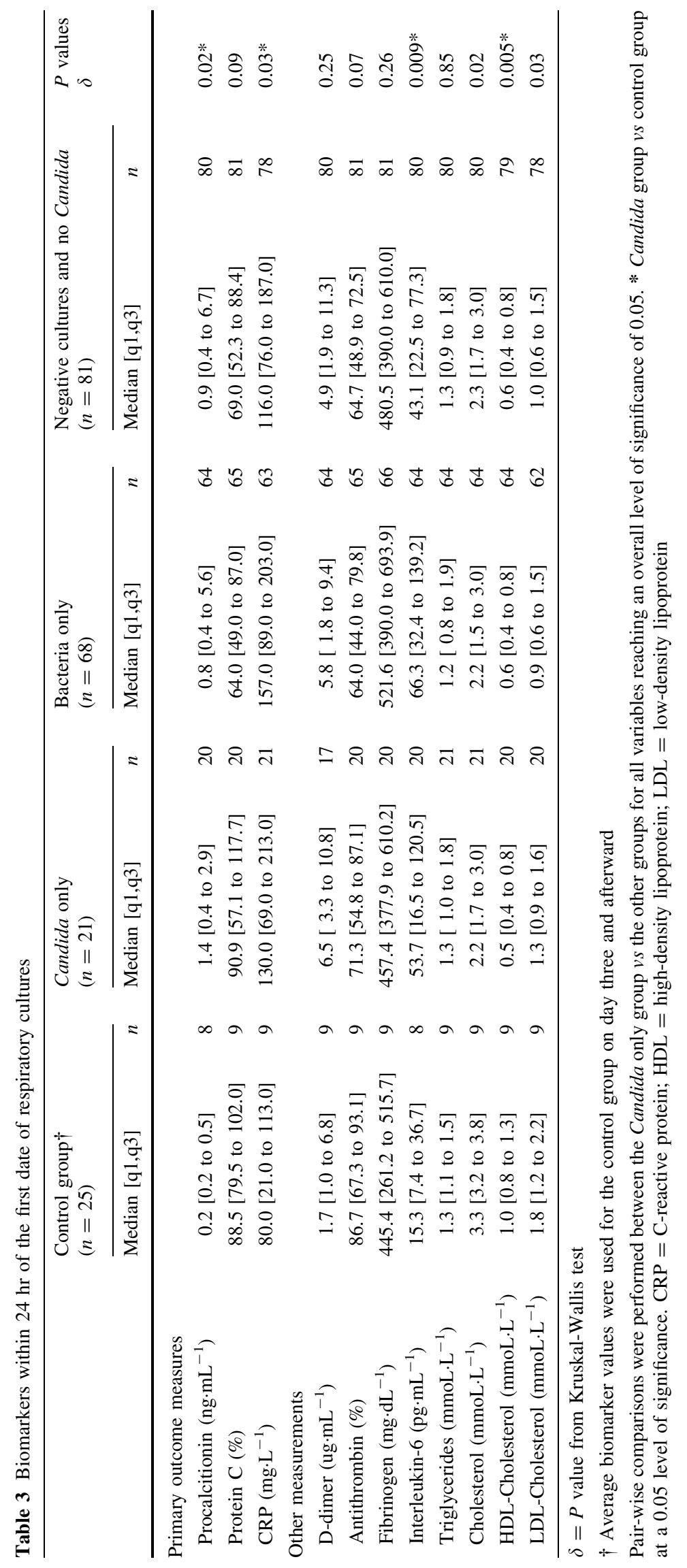


Fig. 2 CRP $($ Mean \pm SE)

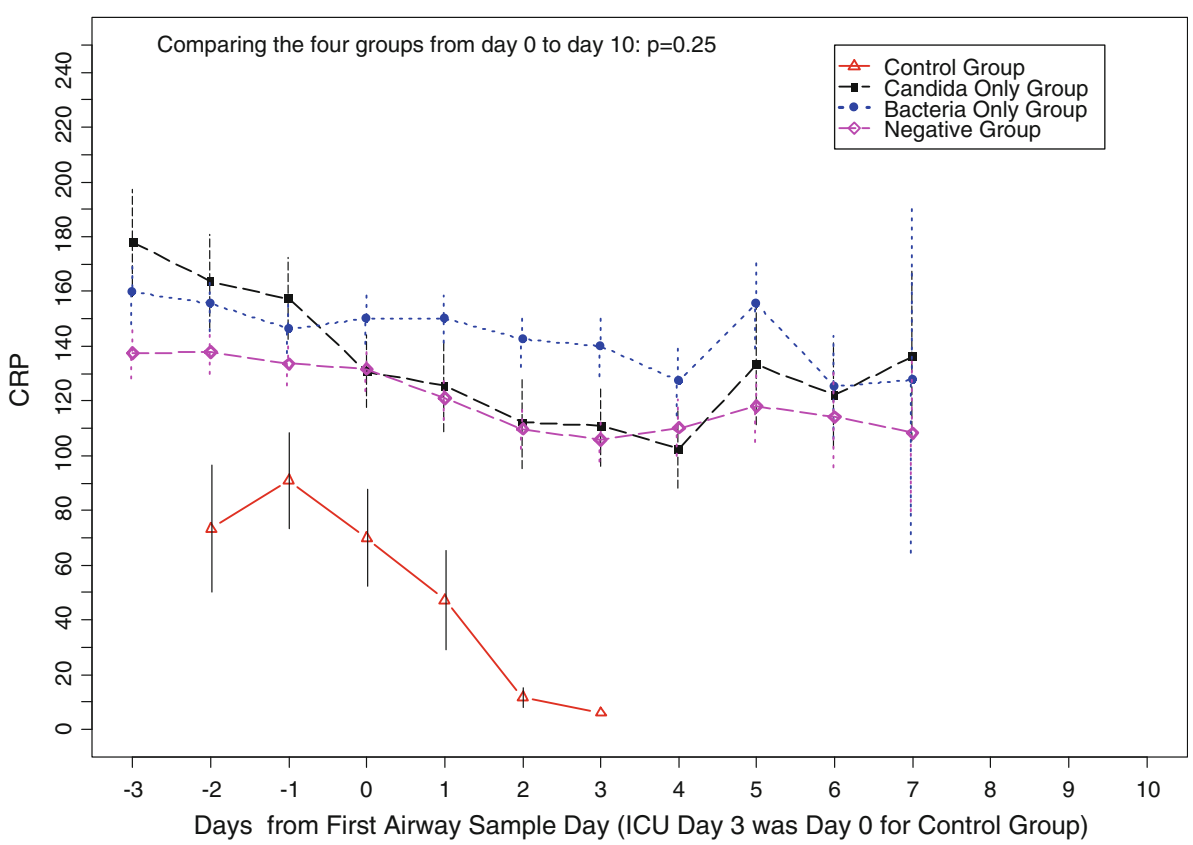

Fig. 3 Log(IL-6) (Mean \pm SE)

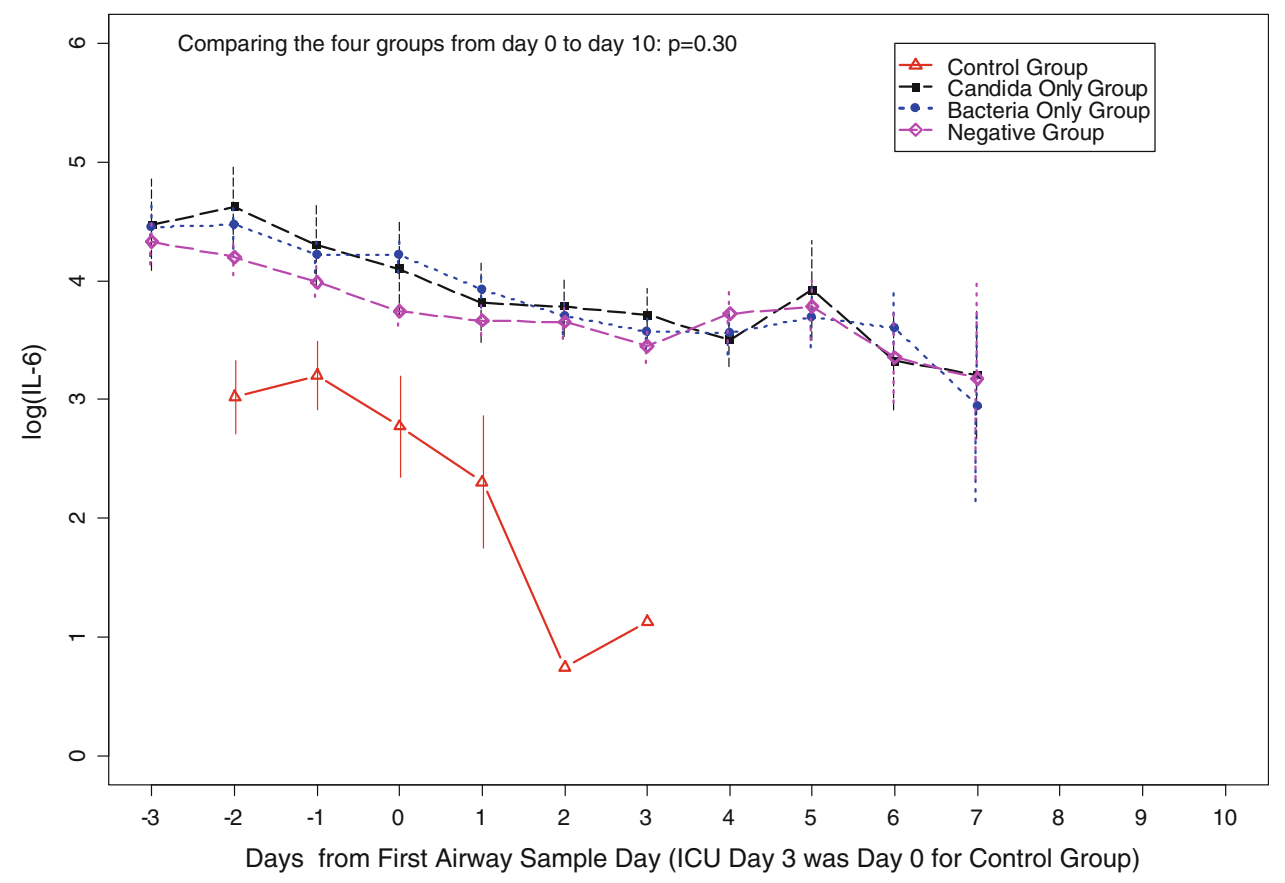

markers, such as IL- 1 and TNF- $\alpha$, through NF- $\kappa \mathrm{B}$ activation, trigger fungicidal responses, and generate reactive oxygen intermediates. ${ }^{29-32}$ These observations provide a mechanism by which Candida may play a causal role in the increased inflammatory markers and may potentiate worse clinical outcomes. ${ }^{33}$ In a recent study, rats instilled with live Candida albicans developed increased pulmonary $\mathrm{TNF}-\alpha$ and increased rates of pseudomonal pneumonia; whereas, rats instilled with normal saline or ethanol destroyed the Candida albicans. In critically ill patients, tracheal colonization with Candida $\operatorname{spp} .\left(\geq 10^{3} \cdot \mathrm{L}^{-1}\right)$ within the first four days of mechanical ventilation was associated with greater tracheal IL-8 and IL-6 levels than patients whose tracheas were colonized with bacteria. ${ }^{34}$ The results of the current study may imply that Candida in the RT secretions can play a greater pathophysiological role, as suggested by the increased inflammation observed in the Candida group.

Although our study included a significant number of patients from multiple centres in a prospective fashion and employed standardized inflammatory biomarker analysis, there are a number of limitations to our observations. First, 
Fig. $4 \log$ (Procalcitionin) $($ Mean \pm SE)

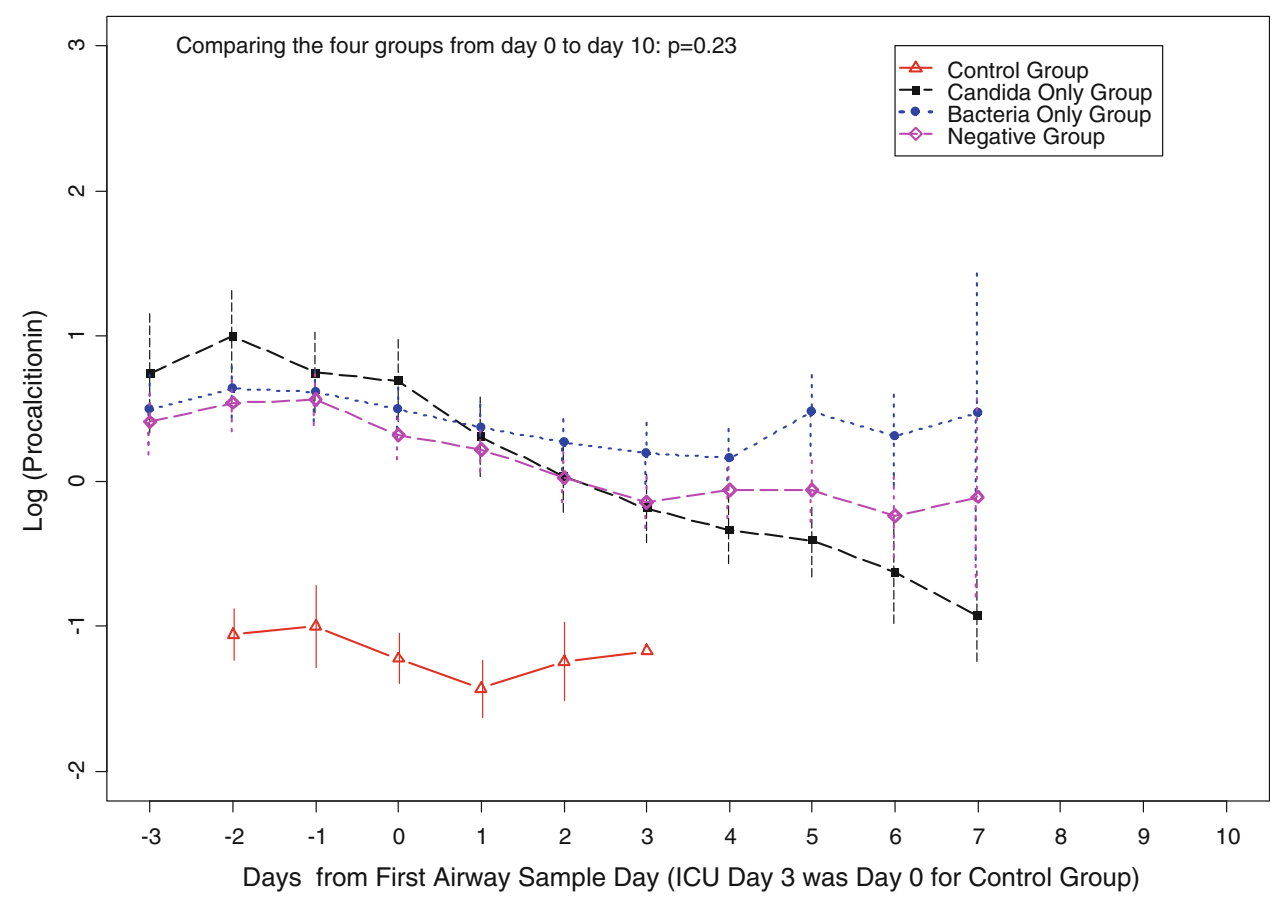

this study included only a small number of patients in the Candida and control groups and excluded a large number of patients from the initial study because no cultures were sent for laboratory analysis. This selection was justified by our goal of obtaining the most robust data possible with regard to the relation between Candida spp. and systemic inflammation. Second, the definition of suspected VAP was applied retrospectively to our data set and may have resulted in some misclassification. Third, bacteria or viruses that could have been detected using molecular techniques may have been missed with the traditional culture techniques. ${ }^{35}$ Fourth, the group described as having no bacteria included 29 patients $(35.8 \%)$ with commensal bacterial flora. These patients could have artificially increased the median levels of inflammatory markers in this group, thus obscuring differences between it and the Candida only group. Fifth, patients in the Candida group had the highest proportion of prior use of antibiotics; thus, bacterial cultures may have been negative at the time of sampling in some patients. Finally, the Candida cultures were qualitative and were not speciated or quantified. Perhaps greater quantities of Candida organisms or a specific threshold of organisms would enhance the level of systemic inflammation. Also, we did not systematically screen for Candida from all sites, including the gastrointestinal tract, so we cannot be certain as to the determination of widespread Candida colonization. However, blood and urine cultures were drawn from all study subjects at the same time, and we did exclude patients with documented presence of Candida spp. from other sources; therefore, the probability of disseminated candidiasis is very low.
We have demonstrated that the presence of Candida spp. in the RT, in comparison with the presence of bacterial pathogens or no pathogens, is associated with comparable systemic inflammation and may be associated with worse clinical outcomes. Future studies should target the pathogenic role that Candida plays to affect outcomes in this patient population. Based on these results and the results of previous studies, a placebo-controlled trial evaluating the role of antifungal treatment on the inflammatory cytokine profiles and clinical outcomes is warranted and is now underway. (ClinicalTrials.gov number, NCT00934934).

Financial disclosure and competing interests None declared.

\section{References}

1. Vincent JL, Bihari DJ, Suter PM, et al. The prevalence of nosocomial infection in intensive care units in Europe. Results of the European Prevalence of Infection in Intensive Care (EPIC) Study. EPIC International Advisory Committee. JAMA 1995; 274: 63944.

2. Richards MJ, Edwards JR, Culver DH, Gaynes RP. Nosocomial infections in combined medical-surgical intensive care units in the United States. Infect Control Hosp Epidemiol 2000; 21: 510-5.

3. Heyland DK, Cook DJ, Griffith L, Keenan SP, Brun-Buisson C. The attributable morbidity and mortality of ventilator-associated pneumonia in the critically ill patient. The Canadian Critical Trials Group. Am J Respir Crit Care Med 1999; 159: 1249-56.

4. National Nosocomial Infections Surveillance System. National Nosocomial Infections Surveillance (NNIS) System Report, data summary from January 1992 through June 2004, issued October 2004. Am J Infect Control 2004; 32: 470-85. 
5. Bueno-Cavanillas A, Delgado-Rodriguez M, Lopez-Luque A, Schaffino-Cano $S$, Galvez-Vargas $R$. Influence of nosocomial infection on mortality rate in an intensive care unit. Crit Care Med 1994; 22: 55-60.

6. Safdar N, Dezfulian C, Collard HR, Saint S. Clinical and economic consequences of ventilator-associated pneumonia: a systematic review. Crit Care Med 2005; 33: 2184-93.

7. Warren DK, Shukla SJ, Olsen MA, et al. Outcome and attributable cost of ventilator-associated pneumonia among intensive care unit patients in a suburban medical center. Crit Care Med 2003; 31: 1312-7.

8. Muscedere JG, Martin CM, Heyland DK. The impact of ventilator-associated pneumonia on the Canadian health care system. J Crit Care 2008; 23: 5-10.

9. Chastre J, Fagon JY. Ventilator-associated pneumonia. Am J Respir Crit Care Med 2002; 165: 867-903.

10. The Canadian Critical Care Trials Group. A randomized trial of diagnostic techniques for ventilator-associated pneumonia. N Engl J Med 2006; 355: 2619-30.

11. Kollef MH, Morrow LE, Niederman MS, et al. Clinical characteristics and treatment patterns among patients with ventilatorassociated pneumonia. Chest 2006; 129: 1210-8.

12. Meersseman W, Lagrou K, Spriet I, et al. Significance of the isolation of Candida species from airway samples in critically ill patients: a prospective, autopsy study. Intensive Care Med 2009; 35: 1526-31.

13. el-Ebiary $M$, Torres A, Fabregas $N$, et al. Significance of the isolation of Candida species from respiratory samples in critically ill, non-neutropenic patients. An immediate postmortem histologic study. Am J Respir Crit Care Med 1997; 156: 583-90.

14. Rello J, Esandi ME, Diaz E, Mariscal D, Gallego M, Valles J. The role of Candida sp isolated from bronchoscopic samples in nonneutropenic patients. Chest 1998; 114: 146-9.

15. Wey SB, Mori M, Pfaller MA, Woolson RF, Wenzel RP. Risk factors for hospital-acquired candidemia. A matched case-control study. Arch Intern Med 1989; 149: 2349-53.

16. Magill SS, Swoboda SM, Johnson EA, et al. The association between anatomic site of Candida colonization, invasive candidiasis, and mortality in critically ill surgical patients. Diagn Microbiol Infect Dis 2006; 55: 293-301.

17. Delisle MS, Williamson DR, Perreault MM, Albert M, Jiang X, Heyland $D K$. The clinical significance of Candida colonization of respiratory tract secretions in critically ill patients. J Crit Care 2008; 23: 11-7.

18. Azoulay E, Timsit JF, Tafflet $M$, et al. Candida colonization of the respiratory tract and subsequent pseudomonas ventilator-associated pneumonia. Chest 2006; 129: 110-7.

19. Calderon EJ, Rivero L, Respaldiza $N$, et al. Systemic inflammation in patients with chronic obstructive pulmonary disease who are colonized with Pneumocystis jiroveci. Clin Infect Dis 2007; 45: e17-9.

20. Kellum JA, Kong L, Fink MP, et al. Understanding the inflammatory cytokine response in pneumonia and sepsis: results of the Genetic and Inflammatory Markers of Sepsis (GenIMS) Study. Arch Intern Med 2007; 167: 1655-63.
21. Jensen JU, Heslet L, Jensen TH, Espersen K, Steffensen P, Tvede $M$. Procalcitonin increase in early identification of critically ill patients at high risk of mortality. Crit Care Med 2006; 34: 2596602.

22. Knaus WA, Draper EA, Wagner DP, Zimmerman JE. APACHE II: a severity of disease classification system. Crit Care Med 1985; 13: 818-29.

23. Vincent JL, Moreno R, Takala J, et al. The SOFA (Sepsis-related Organ Failure Assessment) score to describe organ dysfunction/ failure. On behalf of the Working Group on Sepsis-Related Problems of the European Society of Intensive Care Medicine. Intensive Care Med 1996; 22: 707-10.

24. Krause W, Matheis $H$, Wulf $K$. Fungaemia and funguria after oral administration of Candida albicans. Lancet 1969; 1: 598-9.

25. Pittet D, Monod M, Suter PM, Frenk E, Auckenthaler R. Candida colonization and subsequent infections in critically ill surgical patients. Ann Surg 1994; 220: 751-8.

26. Young SH, Ostroff GR, Zeidler-Erdely PC, Roberts JR, Antonini $J M$, Castranova $V$. A comparison of the pulmonary inflammatory potential of different components of yeast cell wall. J Toxicol Environ Health A 2007; 70: 1116-24.

27. Muller V, Viemann D, Schmidt M, et al. Candida albicans triggers activation of distinct signaling pathways to establish a proinflammatory gene expression program in primary human endothelial cells. J Immunol 2007; 179: 8435-45.

28. Inoue $\mathrm{K}$, Takano $\mathrm{H}$, Oda $\mathrm{T}$, et al. Candida soluble cell wall betaD-glucan induces lung inflammation in mice. Int J Immunopathol Pharmacol 2007; 20: 499-508.

29. Lebron F, Vassallo R, Puri V, Limper AH. Pneumocystis carinii cell wall beta-glucans initiate macrophage inflammatory responses through NF-kappaB activation. J Biol Chem 2003; 278: 25001-8.

30. Hahn PY, Evans SE, Kottom TJ, Standing JE, Pagano RE, Limper $A H$. Pneumocystis carinii cell wall beta-glucan induces release of macrophage inflammatory protein-2 from alveolar epithelial cells via a lactosylceramide-mediated mechanism. J Biol Chem 2003; 278: 2043-50.

31. McCann F, Carmona E, Puri V, Pagano RE, Limper AH. Macrophage internalization of fungal beta-glucans is not necessary for initiation of related inflammatory responses. Infect Immun 2005; 73: $6340-9$

32. Wheeler RT, Fink GR. A drug-sensitive genetic network masks fungi from the immune system. PLoS Pathog 2006; 2: e35.

33. Varela JM, Respaldiza N, Sanchez B, et al. Lymphocyte response in subjects with chronic pulmonary disease colonized by Pneumocystis jirovecii. J Eukaryot Microbiol 2003; 50(Suppl): 672-3.

34. Durairaj L, Mohamad Z, Launspach JL, et al. Patterns and density of early tracheal colonization in intensive care unit patients. J Crit Care 2009; 24: 114-21.

35. Chiche L, Forel JM, Roch A, et al. Active cytomegalovirus infection is common in mechanically ventilated medical intensive care unit patients. Crit Care Med 2009; 37: 1850-7. 